\title{
PSIKOEDUKASI PENDIDIKAN SEKSUALITAS: “LOVE, SEX AND DATING” PADA REMAJA
}

\author{
Krishervina Rani Lidiawati ${ }^{1}$, Erni Julianti Simanjuntak ${ }^{2}$, Wiwit Puspitasari Dewi ${ }^{3}$ \\ Universitas Pelita Harapan
}

krishervina.lidiawati@uph.edu,erni.simanjuntak@uph.edu,wiwit.dewi@uph.edu

\begin{abstract}
Abstrak
Remaja dijelaskan sebagai masa transisi atau peralihan dari kanak-kanak menuju dewasa dan tahap terjadinya kematangan seksual atau dikenal dengan istilah pubertas. Perubahan-perubahan secara fisik ini belum diikuti kematangan dalam berpikir jangka Panjang sehingga pengambilan keputusan kerapkali kurang mempertimbangkan resikonya. Pada masa pubertas ini, banyak remaja yang menjalin hubungan dan memiliki kedekatan dengan pasangan lawan jenis (Dari \& Ratnawati, 2015). Terbatas dan kurangnya pemngetahuan dalam memahani love, sex dan dating berdampak pada gaya pacaran yang salah atau tidak sehat. Salah satu indikasi pacaran yang tidak sehat adalah terlibat dalam perilaku seks beresiko dan dampak yang dapat ditimbulkan yaitu, hamil di usia dini, HIV/AIDS, dan infeksi menular seksual. Menanggapi fenomena sosial yangberkembang dalam kehidupan remaja dewasa ini, maka pengabdian masyarakat dilakukan dalam bentuk seminar untuk mengedukasi siswa remaja SMA tentang love, Sex and Dating (LSD). Diharapkan melalui psikoedukasi ini, siswa dapat memahami perilaku-perilaku LSD yang sesuai dengan usia mereka dan dapat diterima dalam masyarakat. Berdasarkan hasil evaluasi 61 siswa dapat memahami definisi cinta, pacaran yang sehat dan tujuan dari pacaran.
\end{abstract}

Kata Kunci: pendidikan seksual, remaja

\section{PENDAHULUAN}

Berdasarkan data yang diperoleh dari Badan Kesehatan Dunia (WHO) menunjukkan bahwa, persentase remaja adalah seperlima dari penduduk di dunia, dengan 900 juta berada pada negara berkembang dan terhitung di Indonesia sekitar 20 persen (Marlita, 2019). Remaja dijelaskan sebagai masa transisi atau peralihan dari kanak-kanak menuju dewasa dan merupakan tahap terjadinya kematangan seksual (Goddings, Beltz, Peper, Crone, \& Braams, 2019). Kematangan seksual mendorong remaja untuk menjalin hubungan dan memiliki kedekatan dengan pasangan lawan jenis. Kematangan seksual ditandai salah satunya dengan kematangan alat reproduksi, dan hal ini merupakan proses yang terjadi secara alami di dalam diri setiap individu. Kematangan ini juga yang menjadi salah satu faktor timbulnya perasaan suka atau ketertarikan antar lawan jenis. Adanya perasaan suka atau ketertarikan dengan lawan jenis ini membuat para remaja mengenal istilah kencan ("dating") yang berlajut dalam hubungan pacaran di usia remaja.

Konsep pacaran yang seharusnya adalah sebagai tahapan sebelum pernikahan, di mana kedua individu saling mencintai dan mengasihi (Dari \& Ratnawati, 2015). Penjelasan tersebut menunjukkan bahwa, pacaran seharusnya dilakukan bagi seseorang yang sudah memikirkan hubungan jangka panjang kepada jenjang pernikahan. Sedangkan, masa remaja 
sebagai masa transisi dari anak-anak menuju dewasa yang secara emosional belum siap untuk menikah. Selain itu, remaja umumnya belum memiliki bekal yang cukup untuk membangun rumah tangga. Namun dilihat dari kenyataan yang terjadi di lapangan, didapati bahwa remaja pacaran disebabkan karena gengsi, fantasi, maupun sebagai bentuk eksplorasi seks (Hanifah, 2010 dalam Dari \& Ratnawati, 2015).

Orientasi yang salah dalam pacaran dapat mempengaruhi gaya pacaran yang salah atau tidak sehat. Salah satu indikasi pacaran yang tidak sehat adalah terlibat dalam perilaku seksual. Seperti yang kita ketahui, dampak yang dapat ditimbulkan yaitu kehamilan di usia dini, HIV/AIDS, dan infeksi menular seksual (Evi, Nasir \& Suriah, 2013). Berdasarkan data yang diperoleh dari hasil riset Komisi Perlindungan Anak Indonesia (KPAI) menunjukkan terjadinya peningkatan perilaku seksual pada remaja setiap tahun. Pada tahun 2013, sebanyak 32\% remaja di kota besar Indonesia (Jakarta, Surabaya, dan Bandung) pada rentang usia 14 sampai 18 tahun sudah melakukan hubungan seksual (Marlita dkk, 2019). Selanjutnya, pada tahun 2015 menunjukkan bahwa, perilaku seksual di Indonesia dengan persentase yang didapat sebanyak 93,75\% pernah terlibat dalam melakukan adegan intim dan sampai melakukan seks oral (Marlita dkk, 2019). Selain itu, penelitian yang dilakukan oleh Badan Kependudukan dan Keluarga Berencana Nasional (BKKBN) pada 1000 remaja di Jawa Barat menunjukkan data bahwa 100 orang tidak perawan lagi dan 80 orang diantaranya sudah memiliki anak (Heryana, 2011 dalam Dari \& Ratnawati, 2019).

Data-data yang telah disampaikan di atas tentunya mengkhawatirkan kehidupan atau gaya berpacaran dari para remaja karena dampak yang diakibatkan bersifat jangka panjang. Namun, terlepas dari peristiwa yang terjadi di atas, kita perlu melihat juga faktor-faktor lain yang memengaruhi remaja sampai terjerumus ke dalam bentuk pergaulan atau pacaran yang tidak sehat. Salah satu faktor yang paling mempengaruhi (selain lingkungan dan teman sebaya dan pola asuh) (Amalia, 2012 dalam Dari \& Ratnawati, 2019), (Nursal, 2007; Saputri, 2015 dalam, Kartika \& Budisetyani, 2018) adalah kurangnya pengetahuan tentang pendidikan seks yang merupakan salah satu komponen yang dapat membentuk perilaku beresiko dan perilaku seksual pranikah (Pratama, E., Hayati, S. \& Supriatin, E., 2014)

Menanggapi fenomena sosial yang berkembang dalam kehidupan remaja dewasa ini, maka akan dilakukan kegiatan psikoedukasi pendidikan seksual kepada remaja. Hal ini terkait dengan beberapa kasus dan perilaku beresiko yang rentan terjadi pada remaja yang juga semakin marak di beberapa daerah di Indonesia (Badan Pusat Statistik, Badan Koordinasi Keluarga Berencanan Nasional, Departemen Kesehatan, \& Macro International, 2013).

Pendidikan seksualitas mencakup pertanyaan dan jawaban yang berkaitan dengan pengetahuan seksualitas. Pendidikan seksualitas merupakan upaya pemberian pemahaman kepada anak-anak sesuai dengan usianya mengenai fungsi alat reproduksi dan alat kelamin. Beberapa tema yang biasanya juga ditanyakan oleh remaja seperti kehawatiran tentang masa transisi dari anakanak ke dewasa yaitu pubertas pada masa remaja, infeksi penyakit menular (IMS), HIV/AIDS, kehamilan, alat kontrasepsi dan berbagai mitos atau kesalahpahaman yang terlanjur menyebar luas di masyarakat (SIECUS, 2004; UNESCO, 2018).

Oleh karena itu maka pengabdian masyarakat ini bertujuan untuk mengedukasi remaja tentang Love, Sex and Dating (LSD). Melalui kegiatan ini diharapkan siswa dapat memahami perilaku-perilaku LSD yang sesuai dengan usia mereka dan dapat diterima dalam masyarakat. Kegiatan ini secara lebih jauh juga memberikan informasi tentang tentang pelecehan seksual. Hal ini dilakukan guna menghindari pelecehan seksual dan mengetahui hal yang harus dilakukan bila menjadi saksi/korban dalam pelecehan seksual.

Secara khusus pendidikan seksual ini ditujukan pada remaja yang masih duduk di bangku SMA (Sekolah Menengah Atas). Hal ini dikarenakan adanya banyak siswa-siswi SMA yang mulai terlibat dalam perilaku berpacaran atau mulai tertarik dengan lawan jenis. Kegiatan ini diinisisasi oleh salah satu sekolah menengah atas di Tangerang dan mengundang tim Psikologi Universitas Pelita Harapan (UPH) melalui marketing UPH untuk mengadakan sebuah kegiatan pengabdian masyarakat, yaitu SMA Tunas Mulia di Gading Serpong. Kegiatan pengabdian masyarakat yang akan dilaksanakan berupa seminar psikologi atau 
psikoedukasi. Kegiatan seminar yang dilakukan memuat informasi mengenai tentang "Love, Sex and Dating" beserta contoh-contoh fenomena yang terjadi di dunia remaja. Kegiatan ini juga akan melibatkan mahasiswa UPH untuk berpartisipasi dalam berlangsungnya seminar seperti memberikan ice breaking dan berperan dalam proses diskusi dan tanya jawab.

Akhir kata, kegiatan pengabdian masyarakat yaitu psikoedukasi tentang love, sex and dating ini tentunya sejalan dengan salah satu misi Fakultas Psikologi UPH yaitu pengembangan karakter. Dengan adanya pengetahuan dan pemahaman yang benar tentang bagaimana proses menjalin relasi dengan lawan jenis, cara berpacaran yang sehat berkaitan dengan perilaku sesual, maka diharapkan dapat membantu siswa melewati dan menghadapi krisis maupun isu yang diperhadapkan pada usia mereka yang tidak stabil dan terlebih lagi siswa diharapkan akan memiliki kualitas "value", "attitude" dan "character" positif dalam membangun relasi dengan lawan jenis, memiliki proses dan gaya berpacaran yang sehat yang menjadi dasar bagi mereka untuk menjalani pernikahan dan kehidupan berkeluarga di kemudian hari.

\section{METODE}

Menanggapi persoalan remaja dan fenomena yang terjadi, psikoedukasi ini berupa seminar yang bertemakan: "Love, Sex and Dating". Kegiatan ini dilaksanakan pada hari Selasa, 23 Juli 2019. Jumlah peserta sebanyak 61 siswa.

Psikoedukasi terbagi menjadi empat bagian yaitu 1) Pembukaan yaitu perkenalan, ice breaker, pengisian kuesioner. Ice breaker yang digunakan adalah "tangkap cinta" yang di pimpin oleh mahasiswa. Ice breaker ini bertujuan untuk mencairkan suasana sekaligus untuk masuk ke dalam tema tentang cinta. Setelah ice breaker dilanjutkan pengisian kuesioner tentang pandangan remaja terhadap pacaran; 2) dilanjutkan dengan sesi pertama yaitu "Love" yang dibawakan oleh Erni Simanjuntak selama 30 menit; 3) Sesi kedua membahas tentang "Sex and Dating" dibawakan oleh Krishervina Rani Lidiawati berlangsung selama 45 menit; 4) Penutup yaitu diskusi dan evaluasi. Psikoedukasi ini di akhiri dengan sesi tanya jawab dan lembar evaluasi pelaksanaan seminar. Selama berlangsungnya sesi, mereka diminta turut aktif dalam menyampaikan pendapat mereka tentang mengapa berpacaran, apa tujuan berpacaran, usia menikah yang mereka harapkan dan usia menikah minimal yang sesuai dengan peraturan pemerintah. Sekaligus untuk memberitahukan perilaku-perilaku yang seharusnya tidak terjadi dalam pacaran yaitu pelecehan seksual dan kekerasan dalam berpacaran yang menandakan relasi mereka tidak sehat.

\section{HASIL DAN PEMBAHASAN}

Pendidikan seks merupakan proses pengajaran yang bukan satu kali seumur hidup namun pemahaman yang terus-menerus diberikan kepada anak mengenai sikap, value, dan perkembangan alat-alat reproduksi serta bagaimana menjaganya (UNESCO, 2018). Hal ini tentu bukan tugas sederhana bagi orang tua dan pendidik. Namun pendidikan seksual seharusnya menjadi tanggung jawab orang tua. Maka dari itu orang tua harus memiliki kemampuan untuk dapat meyampaikan pendidikan seks yang baik dan tidak menimbulkan pemahaman yang bias. Namun di Indonesia, sebagian orang tua jarang dan hampir kurang memberikan pendidikan seks untuk anak usia dini bahkan dianggap tabu di kalangan masyarakat (Kemendikbud, 2019). Mereka beranggapan bahwa pendidikan seks belum pantas diberikan pada anak kecil. Padahal dengan pendidikan seks yang diberikan sejak dini sangat berpengaruh dalam kehidupan anak ketika dia memasuki masa remaja.

Apalagi mengingat fenomena dan data perilaku beresiko pada remaja di Indonesia terus meningkat (Badan Pusat Statistik et al., 2013). Itu semua karena pada masa ini, anak-anak memiliki rasa keingintahuan yang besar. Anak-anak yang sekali, dua kali, dan berkali-kali melihat tayangan, maka anak- anak akan merekamnya dan membentuknya menjadi suatu pandangan/nilai seksualitas yang dianutnya hingga dia dewasa. Salah satu cara menyikapi fenomena ini adalah dengan memberikan edukasi seksual yang tepat dengan cara yang tepat sesuai dengan perkembangan anak (UNESCO, 2018).

Pendidikan seksual dapat dimulai dari memberikan pemahaman mengenai cinta dan aspekaspek yang ada dalam relasi yang sehat. Menurut

$$
\text { Kesehatan }
$$


Stenberg, cinta memiliki tiga komponen yaitu intimacy, passion dan commitment. Intimacy merupakan kedekatan secara emosional, perasaan saling terhubung dan memiliki. Hal ini dapat dilihat dimulai dari banyaknya waktu yang kerapkali dihabiskan bersama-sama, pengenalan akan satu dengan yang lain dari mulai hal-hal yang umum hingga bersifat personal seperti latar belakang keluarga. Hal inilah yang membuat individu saling terbuka dan percaya. Komponen kedua adalah passion. Passion merupakan dorongan atau hasrat seksual dan ketertarikan secara fisik. Passion ini kerapkali komponen yang paling menonjol di masa remaja. Komponen berikutnya adalah commitment, yaitu aspek kognitif dalam relasi berkaitan dengan keputusan bahwa pasangan akan saling mencintai satu dengan yang lain dan akan mempertahankan relasi (Draganović \& Hasanagic, 2014).

Adapun berbagai tipe cinta berdasarkan tiga komponen cinta: 1) nonlove yaitu tidak adanya ketiga aspek cinta baik intimacy, commitment dan passion; 2) liking yaitu adanya pengalaman tertarik, memiliki kedekatan secara emosional namun tidak adanya passion dan commitment. Biasanya terjadi karena pertemanan dan banyak menghabiskan waktu Bersama, hal ini biasa terjadi pada anak remaja; 3) empty love yaitu adanya keputusan untuk berkomitmen menjalin relasi meski tidak ada passion dan intimacy, misalnya relasi yang dijodohkan;4) romantic love yaitu adanya intimacy dan passion daam relasi tersebut tanpa adanya commitment, relasi ini banyak terjadi dikalangan remaja; 5) companionate love yaitu adanya komponen intimacy dan commitment, 6) Fatuous love merupakan kombinasi adanya passion dan commitment dalam relasi tanpa adanya intimacy seperti kawin kontrak; 7) consummate or complete love yaitu adanya relasi dengan melibatkan tiga komponen baik intimacy, passion dan commitment (Plotnik \& Kouyoumdjian, 2011).

Pada remaja telah memiliki ketertarikan secara seksual dan itu adalah hal wajar. Namun bukan berarti boleh melakukan hubungan seks (hubungan suami istri) sebelum menikah. Salah satu dari akibat seks bebas adalah kehamilan di luar nikah dan ibu muda yang meninggal. Salah satu program pemerintah melalui program penyuluhan tentang kesehatan reproduksi pun telah dilakukan secara rutin melalui puskesmas (Kementrian Kesehatan,
2014). Namun demikian masih banyak remaja yang belum mendapatkan edukasi tentang kesehatan reproduksi, pencegahan, penanggulangan kehamilan di luar nikah.

Kehamilan di luar nikah tersebut dapat dicegah salah satunya dengan cara memperbaikki konsep berpacaran yang sehat. Berpacaran bukan hanya untuk status atau mengikuti trend remaja. Bahkan beberapa remaja melakukan bullying kepada temannya akibat tidak memiliki pacar. Pacaran merupakan tahap persiapan pernikahan. Dalam relasi berpacaran yang sehat harus saling mendorong pasangan untuk tetap memiliki teman dan dapat mengembangkan potensi yang dimilikki. Beberapa hal yang perlu diwaspadai dalam berpacaran yaitu makin maraknya kekerasan dalam berpacaran baik secara fisik, verbal dan psikologis. Hal ini tersebut tentulah bukan pacaran yang sehat. Oleh karena itu remaja perlu menyadari bahwa pacaran yang sehat tentu memiliki batasan yang sesuai dengan norma dan aturan yang berlaku. Apalagi jika dalam relasi tersebut sampai terjadi pelecehan secara seksual dan tentunya berdampak pada self-esteem individu tersebut (de Lijster, Felten, Kok, \& Kocken, 2016).

Berdasarkan pemaparan diatas maka dapat disimpulkan bahwa remaja penting untuk memahami konsep cinta, seks dan berpacaran yang sehat. Oleh karena itu psikoedukasi tentang Pendidikan seksualitas yang diangkat adalah "Love, Sex and Dating”. Adapun psikoedukasi ini telah dilaksanakan dan diberikan pada siswa SMA yang juga masih dalam tahap remaja. Pemberian materi sesuai dengan tema yang diangkat dan kemudian dilakukan evaluasi.

Evaluasi psikoedukasi dilakukan setelah kegiatan seminar selesai dilakukan. Terdapat 61 peserta yang mengisi pertanyaan terbuka mengenai sejauh mana informasi yang didapatkan, apakah ada pertanyaan lain yang belum terjawab, serta kesan dan saran terkait pelaksanaan seminar. Secara umum peserta menyatakan kesan mereka yang positif terhadap seminar ini. Mereka menganggap topik mengenai pacaran ini penting untuk diberikan pada remaja seusia mereka. Selain itu peserta menganggap seminar ini sangat informatif sehingga mereka juga mendapatkan pengetahuan lebih dalam mengenai topik love, sex, and dating. Peserta menyatakan tidak ada pertanyaan lebih lanjut terkait dengan topik seminar yang disampaikan. Mereka menganggap 
informasi yang diberikan sudah cukup lengkap dan pertanyaan yang dimiliki sudah terjawab dalam pelaksanaan seminar.

Terdapat beberapa informasi yang didapatkan oleh peserta melalui seminar ini yang setelah disimpulkan dapat dibagi menjadi lima tema besar, yaitu:1)Mengetahui lebih lanjut definisi dari cinta, seks, dan berpacaran; 2)Memahami pentingnya masa remaja dan masa depannya, sehingga belajar untuk menjadi remaja yang lebih baik; 3) Memahami perilaku berpacaran yang sehat baik secara fisik maupun rohani. Dalam hal ini peserta menjadi tahu apa yang dapat dilakukan dan juga perlu dihindari saat pacaran serta menyadari pentingnya pengendalian diri;4) Memahami lebih lanjut mengenai sex education, di mana peserta jadi memahami dampak perilaku seksual sebelum menikah; 5) Menyadari bahwa masa pacaran merupakan salah satu persiapan untuk menikah, sehingga perlu memilih pasangan dengan baik.

Diharapkan informasi yang telah didapatkan dapat juga dibagikan kepada teman-teman sebayanya sehingga tidak terjebak dalam perilaku beresiko. Hal ini dikarenakan adanya pengaruh teman sebaya dapat memengaruhi perilaku remaja lainnya. Diharapkan melalui remaja yang sudah mendapatkan edukasi dapat memberikan edukasi kepada remaja lainnya (Price \& Knibbs, 2009). Selain itu, diharapkan akan dilakukannya semiar edukasi tentang pendidikan seksual secara rutin oleh pihak konselor sekolah atau pihak professional. Hal ini berguna untuk memberikan ruang diskusi secara mendalam serta memfasilitasi remaja yang memiliki pertanyaan namun takut bertanya kepada guru atau orang tua.

\section{KESIMPULAN}

Berdasarkan dari psikoedukasi yang telah dilakukan maka penting adanya seminar "Love, Sex and Dating" ini diperlukan dan dapat dilakukan di sekolah-sekolah lain, bahkan untuk jenjang SMP bukan hanya untuk remaja. Pdikoedukasi ini juga diperlukan seminar bagi orang tua dan guru agar dapat mendampingi putra-putrinya dalam memasuki masa remaja. Hal ini dikarenakan kemajuan teknologi yang memungkinkan remaja semakin cepat memperoleh informasi sehingga diperlukan bimbingan dari orang tua dan guru.

\section{UCAPAN TERIMAKASIH}

Terimkasih kami ucapkan atas kerjasama SMA Tunas Mulia Gading Serpong dan Universitas Pelita Harapan (UPH) sehingga psikoedukasi "Love, Sex and Dating” ini dapat berlajan dengan lancar.

\section{REFERENSI}

Badan Pusat Statistik, Badan Koordinasi Keluarga Berencanan Nasional, Departemen Kesehatan, \& Macro International. (2013). Survei Demografi dan Kesehatan Indonesia 2012. Sdki, $\quad 16 . \quad$ https://doi.org/10.1111/j.14710528.2007.01580.x

Dari, T. S., \& Ratnawati, D. (2015). Hubungan pola asuh orang tua dengan perilaku berpacaran pada remaja di sman 6 depok. Jurnal Keperawatan, 2(2), 125-144.

De Lijster, G. P. A., Felten, H., Kok, G., \& Kocken, P. L. (2016). Effects of an Interactive SchoolBased Program for Preventing Adolescent Sexual Harassment: A Cluster-Randomized Controlled Evaluation Study. Journal of Youth and Adolescence, 45(5), 874-886. https://doi.org/10.1007/s10964-016-0471-9

Draganović, S., \& Hasanagic, A. (2014). Exploring the difference between Turkish and Bosnian students in Triangular Love scale. Epiphany, $7(2)$.

https://doi.org/10.21533/epiphany.v7i2.108

Evi, Nasir, S., \& Suriah . (2013). Perilaku seksual pada remaja yang berpacaran di sma negeri 2 kairatu kabupaten seram bagian barat. Jurnal MKMI, 250-256.

Goddings, A. L., Beltz, A., Peper, J. S., Crone, E. A., \& Braams, B. R. (2019). Understanding the Role of Puberty in Structural and Functional Development of the Adolescent Brain. Journal of Research on Adolescence, 29(1), 32-53. https://doi.org/10.1111/jora.12408. 
Kartika, D., \& Budisetyani, P. W. (2018). Hubungan pola asuh demokratis dengan perilaku seksual pranikah pada remaja di denpasar dan badung. Jurnal Psikologi Udayana, 5(1), 63-71.

Kemendikbud. (2019). Statistik Pendidikan Anak Usia Dini 2018/2019. Pusat Data Dan Statistik Pendidikan Dan Kebudayaan.

Marlita, L., Wulandini, P., Yusmaharni, \& Zega, E.S. (2019). Hubungan pola asuh orang tua dengan perilaku seksual remaja di smk teknologi migas pekanbaru. Jurnal Keperawatan Abdurrab, 2(2), 23-28.

Price, N., \& Knibbs, S. (2009). How effective is peer education in addressing young people's sexual and reproductive health needs in developing countries? Children and Society, 23(4), 291$302 . \quad$ https://doi.org/10.1111/j.1099- 0860.2008.00175.x

Plotnik R. \& Kouyoumdjian H., (2011). Introduction to Psychology. Wadsworth Cengage Learning, USA.

SIECUS. (2004). Guidelines for Comprehensive Sexuality Education: Kindergarten-12th Grade. Education, 112. Retrieved from http://siecus.org/_data/global/images/guideline s.pdf

UNESCO. (2018). International technical guidance on sexuality education. In Unesco. https://doi.org/10.1523/JNEUROSCI.052904.2004 